\title{
Online Learning in Digital Innovations
}

\section{Andi Mariono $^{1 *}$, Bachtiar S Bachri2, Andi Kristanto ${ }^{3}$, Utari Dewi ${ }^{4}$, Alim Sumarno ${ }^{5}$, Citra Fitri Kholidya ${ }^{6}$, Hirnanda Dimas Pradana ${ }^{7}$ D

\section{A R T I C L E I N F O}

Article history:

Received September 07, 2021

Revised September 12, 2021

Accepted October 12, 2021

Available online November 25, 2021

Kata Kunci:

Media, Pembelajaran Online, Inovasi Digital

\section{Keywords:}

Media, Online Learning, Digital

Innovation

DOI:

https://dx.doi.org/10.23887/jet.v5i4.40 115

\begin{abstract}
A B S T R A K
Mahasiswa dan dosen tidak dapat melakukan pembelajaran secara langsung. Hal ini menjadi kendala dalam penyampaian materi oleh dosen. Tujuan penelitian ini adalah mengembangkan pembelajaran daring pada matakuliah Media Pembelajaran berinovasi digital. Penelitian ini menggunakan penelitian pengembangan. Model pengembangan yang digunakan ADDIE (Analyze, Design, Development, Implementation, Evaluation). Subjek penelitian berjumalh 3 ahli yang meliputi ahli materi, ahli media, ahli desain pembelajaran. Subjek uji coba produk yaitu mahasiswa. Metode yang digunakan untuk mengumpulkan data yaitu observasi, kuesioner, dan tes. Instrument yang digunakan untuk mengumpulkan data yaitu kuesioner dan lembar tes. Teknik yang digunakan untuk menganalisis data yaitu analisis deskriptif kualitatif, kuantitatif, dan statistic. Hasil uji ahli materi $90 \%$ dengan kategori "baik sekali". uji ahli desain pembelajaran 90\% "baik sekali", uji ahli media 90\% kategori "baik sekali" dan uji coba pada mahasiswa 95\% kategori "baik sekali". Berdasarkan analisis data, penggunaan pembelajaran daring matakuliah Media Pembelajaran terbukti efektif dalam pembelajaran. Temuan ini dibuktikan adanya perbedaan antara nilai thitung kelas kontrol yang lebih kecil dari pada thitung kelas eksperimen $(3,558<5,610)$. Pengembangan pembelajaran online ini dapat bermanfaat bagi mahasiswa dalam melakukan pembelajaran yang diakibatkan oleh keterbatasan jarak dan waktu. Matakuliah daring ini memiliki nilai inovasi dintaranya uji praktik online secara mandiri menggunakan simulator kamera dilengkapi audio dan video, sehingga pembelajaran ini lebih interaktif.
\end{abstract}

\begin{abstract}
A B S T R A C T
Students and lecturers cannot do direct learning. It is an obstacle in the delivery of material by the lecturer. The purpose of this research is to develop learning in the Digital Learning Learning Media course. This research uses development research - the model development used by ADDIE (Analyze, Design, Development, Implementation, Evaluation). The research subjects are three experts, which include material experts, media experts, learning design experts. The subject of the product trial is students. The methods used to collect data are observation, questionnaires, and tests. The instruments used to collect data are questionnaires and test sheets. The technique used to analyze the data is descriptive qualitative, quantitative, and statistical analysis. The results of the material expert test are $90 \%$ with the "very good" category. $90 \%$ "very good" learning design expert test, $90 \%$ media expert test in the "very good" category, and 95\% student trials in the "very good" category. Based on data analysis, learning media for learning media is proven to be effective in learning. This finding proves a difference between the control class tcount value which is smaller than the experimental class tcount $(3,558<5,610)$. The development of online learning can be helpful for students in carrying out learning caused by the limitations of distance and time. This bold course has innovative values, including independent online practice tests using camera simulators equipped
\end{abstract} with audio and video to make learning more interactive.

This is an open access article under the CC BY-SA license. Copyright (C) 2021 by Author. Published by Universitas Pendidikan Ganesha.

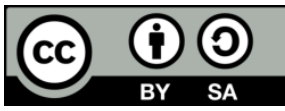

\section{INTRODUCTION}

The advancement of information technology is accelerating due to the availability of internet services. Online device development service providers have facilitated the development of online learning systems (Hwang et al., 2021; Sutarto et al., 2020). The youtube.com website is one of the online media devices that is frequently used as an online learning medium (Anugrahana, 2020; Mahasneh et al., 2021). In Indonesia, online education serves as a foundation for distance education. Distance Learning is mandated by the Regulation of The purpose of the Implementation of Distance Education in Higher Education is to increase the expansion and equitable distribution of educational opportunities, thereby making it easier for universities to provide high- 
quality, relevant education and learning (Bosshardt \& Chiang, 2018; Tajvidi et al., 2014). Currently, e-learning is a necessary component of education. Along with traditional or classical lectures, online lectures, or what is commonly referred to as e-learning, is one method that can be used to innovate learning (Duncan et al., 2013; Kebritchi et al., 2017). The use of technology in everyday life and in the process learning needs to be used wisely so that the benefits can be maximized and according to needs (Chang et al., 2021; Chin \& Wang, 2021). The need for educational innovation exists because, in addition to the rapid advancement of information technology, the number of students enrolled in higher education continues to grow (Bervell \& Arkorful, 2020; Sadegi, 2019). Additionally, one of the benefits of online lectures is that students can interact with learning resources at any time and from any location, because learning resources have been packaged electronically and made accessible to students via online learning (Beaunoyer et al., 2020; Hwang et al., 2021). One of the competencies required in the workplace in the twenty-first century and the industrial revolution 4.0 era is competence in the use of digital technology (Hashim, 2018; Islam Sarker et al., 2019).

Learning is a process that students engage in in order to accomplish learning objectives (Anggrellanggi et al., 2020; Molina et al., 2018). Students are involved in problem solving through the design of artifacts in project-based learning (Chao et al., 2017; Koh et al., 2010). Online education is the type of education that is required today. As objects in the industrial era 4.0, we are compelled to follow developing trends. Online education can assist students in comprehending the material. Online education allows for greater flexibility in the classroom because it can be accessed from anywhere and at any time. Numerous academic institutions that were previously hesitant to alter their traditional pedagogical approach were forced to make a complete shift to online teaching-learning (Dhawan, 2020; Ali Sadikin \& Hamidah, 2020). Schools and universities agreed to change learning activities towards distance learning systems (Kalyuga, 2012; Richardson et al., 2016). The issue that researchers at the S1 Educational Technology Study Program at the State University of Surabaya encountered was the issue of learning in media courses. The impediment exists because students and lecturers are unable to conduct learning directly. This becomes an impediment to the lecturer's delivery of material. If this issue persists, it will have a significant effect on student competence. Media literacy is a required component of the S1 Educational Technology study program. As a result, this issue must be addressed immediately to ensure that learning continues to occur effectively even when students and lecturers do not meet in person.

When learning media lectures are used, the learning process is still conducted in the traditional manner. Thus, when a pandemic strikes and universities are forced to transition to online learning, learning must also migrate to online learning. This is reinforced by research findings that the learning process must be conducted effectively via online education (Sintema, 2020; Yustika et al., 2019). Industry 4.0 development requires an increase in teacher innovation (Y Helsa et al., 2021; Lapada et al., 2020). One of the fundamental principles is that learning should be centered on the student. Students are positioned as active learners throughout their studies (Desyandri et al., 2019; Kristanto, 2021). When the learning process is monotonous, student motivation is low. To facilitate this, innovation is used to create an online learning environment that maximizes the learning experience for students (Joshi et al., 2020; Richardson et al., 2016). Students at Unesa educational technology can also collaborate with students from other universities via online learning, specifically education technology at the State University of Malang. Many educators, particularly in higher education institutions, have embraced online learning due to the benefits it provides to both students and teachers (Alodwan \& Almosa, 2018; Idris et al., 2018).

State University of Malang, as East Java's first LPTK, laid the groundwork for the establishment of subsequent LPTKs, including State University of Surabaya. The State University of Surabaya's history began with the forerunner of Surabaya's integration of B-I and B-II courses, and then as FKIP in 1960. Then, in 1961, FKIP was integrated into the University of Malang as a student. As such, the State University of Malang was chosen as a collaborator for the development of this online module to supplement pedagogical scientific content. Meanwhile, Unesa has a role to play in facilitating technological and digital innovation. According to what is stated in Peraturan Rektor Universitas Negeri Surabaya Nomor 5 tahun 2017 Regarding Article 6 paragraph 1 of the Guidelines for the Implementation of E-Learning, which states: "E-learning students are Unesa students and/or students from other universities who have collaborated with UNESA," and Article 13 regarding credit transfer collection, it is hoped that the two parties will cooperate without incident. The chosen subject is educational media, specifically photography media, which teaches students how to create photo media for educational purposes. In the even semester of 2020/2021, this course carries a credit load of four. Thus far, instruction has taken the form of lectures, presentations, and discussions, with lectures conducted face-to-face in class. As a result, innovative efforts are required to address the issue of limited classroom space when lectures are delivered via an online model. One of these efforts is to conduct hybrid learning, which is distance learning conducted online via the internet (e-learning), in order to ensure that the student learning process runs smoothly and with the highest possible quality (Cavanagh et al., 2020; Sidhu \& Gage, 2021). Assignments are used to evaluate student learning, which means that all student assignments must be submitted online (Putri, 2020; Waqar et al., 2016). This not only reduces the printing costs borne by students, but it also reduces the amount of 
paper used. When students submit assignments online, they enable course tutors to easily correct them. Additionally, this system teaches students to submit assignments on time, as a time limit is automatically imposed if a student is late. Along with assignments, students are evaluated on their learning by taking online quizzes. At the conclusion of the quiz, this quiz will automatically assess the results of student work, assisting the lecturer in the correction process. From a student's perspective, the cause is that students have not yet engaged in maximal learning activities due to a deficiency in critical thinking (Astuti et al., 2021; Purwitaningrum \& Prahmana, 2021).

The use of learning media for synchronous and asynchronous activities can assist students in comprehending learning (Amiti, 2020; Ogbonna et al., 2019). E-learning courses have become a popular method of imparting knowledge to students in institutions of higher learning (Morze et al., 2021; Nuryadi et al., 2020). Online learning refers to educational activities that take place over the Internet and require teachers to upload instructional materials to the platform (Summak et al., 2010; Tang et al., 2021). One way to address this issue is through the creation and implementation of digital learning innovations (Benavides-Varela et al., 2020; Khairudin et al., 2019). Online learning tools and facilities take the form of learning resources that are equipped with web pages and can be accessed independently by students. Instructional materials in the form of instructional videos. The innovation resulting from the development of online learning is a camera simulator that students can use interactively. Students can self-assess their learning outcomes using an assessment menu. Confirmed by numerous research findings indicating that online learning can be conducted in a flexible manner and encourages students to engage in independent learning (Richardson et al., 2016; A. Sadikin \& Hamidah, 2020). Lecturers must actively motivate students to adapt to social changes in the field of digital technology and foster a positive learning environment through online instruction (Astuti et al., 2021; Wijaya et al., 2021). Online learning media can be defined as those that are equipped with control devices that enable users to operate and access what they require, such as downloading resources for educational materials (Kristanto et al., 2021; Udayani et al., 2021). Additionally, online research findings can increase student motivation when they align with research findings. (Astuti et al., 2021; Fitriyani et al., 2020). Since the emergence of online learning, many educational institutions have used a variety of internet applications in the process of teaching and learning (Qazi et al., 2020; Satyawan et al., 2020). However, the utilization of these applications was restricted to some educational institutions in the world in general, and open universities in particular. The purpose of this research is to develop learning in the Digital Learning Learning Media course. It is hoped that bold learning will help students in independent learning.

\section{METHOD}

The research method used in this study is development research. Development research is a subset of research that focuses on resolving problems encountered in the field. This study's development research model is based on the ADDIE development model. of learning development. The ADDIE model is well-suited for use in developing online learning. This is due to the model's high level of complexity and coherence. Because the explanations and stages are easily applicable, the ADDIE model can assist researchers in developing learning. One of the competencies required in the workplace in the twenty-first century and the industrial revolution 4.0 era is competence in the use of digital technology (Yullys Helsa \& Kenedi, 2019).

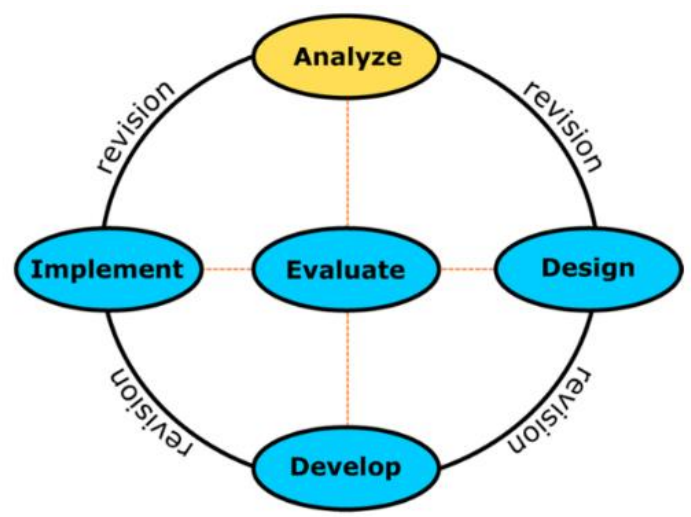

Picture 1. ADDIE Model Development (Wulandari et al., 2020)

The ADDIE model is a simple-to-implement learning system design model that illustrates the fundamental stages of a learning system (Cahyadi, 2019). These phases serve as dynamic and adaptable 
frameworks for effective and efficient instruction (Alodwan \& Almosa, 2018). We will describe the ADDIE development model in the following sections. The subjects of this study were students enrolled in S1 Educational Technology courses at the State University of Surabaya. Along with students as research subjects, the researchers used three experts in their fields as data sources: a material expert, a learning design expert, and a media expert. Observation, interviews, and questionnaires are used to collect data. Through the use of a data retrieval technique.

The ADDIE model was used to develop this online learning. Additionally, the ADDIE model is a systematic model with revision stages at each step. Thus, each stage can be evaluated to ensure that development errors are minimized. The term is nearly synonymous with instructional system development. When used in development, this process is considered sequential but also interactive, as the results of each stage's evaluation can be used to advance the learning process to the next stage. The model's stages are as follows: analysis, design, development, implementation, and evaluation. Additionally, the subject of this research is State University of Surabaya and State University of Malang students who are enrolled in media education courses. The research was conducted using a variety of pre-existing theories. These are theories about online learning, development models, and how developed learning models can be used effectively in learning. The study's learning model is an online learning model, or what is commonly referred to as online learning. This instrument collects data through the use of questionnaires and tests. The Guttman scale is used to analyze the questionnaire data. The Guttman scale is a decomposition scale used to elicit a firm response from respondents with a firm response, namely "yesno." (Sugiyono, 2016). For measurement and instrument validation, a latent variance-based structural equation model approach was used. The technique used to analyze the data is descriptive qualitative and quantitative analysis.

\section{RESULT AND DISCUSSION}

\section{Result}

The analysis section conducts a needs analysis, an audience analysis, a topic analysis, and a task analysis. The Learning Media course is taught at several other universities as part of the same study program, namely the Education Technology study program at both State University of Surabaya and State University of Malang. It examines the rationale for using learning media. Thus, the requirement for these courses serves as a foundation for administering online courses. The host university's curriculum and learning outcomes are the foundation for developing and implementing this course. As a result, this program is co-organized by the Education Technology Study Program at the State University of Surabaya and the Education Technology Study Program at the State University of Malang. Additionally, both universities have a support system in place to facilitate the implementation of online lectures. This design stage is about planning for the implementation of online learning through the creation of a learning environment on the LMS with the URL https://spada.tp.ac.id. This design stage is where the developer will plan the project he is developing (development of a product). Numerous products fail or do not work as a result of the design not being mature or ready but being compelled to continue (Desyandri et al., 2019). The stages begin with the development of materials, activities in online learning, the provision of discussion forums via chat rooms, and the provision of virtual face-to-face forums via the big blue button.

The development stage involves the process of integrating technology, management, and educational processes. Additionally, learning designers have begun to develop and produce high-quality educational materials, beginning with design, instructional materials, and the learning process. The primary aspect of online education is the learning resources. The State University of Surabaya collaborates on the development of online courses with the State University of Malang via the LMS accessible at https://spada.tp.ac.id. Lecturers develop courses using this system, which includes a variety of sources/teaching materials such as presentation files, simulator applications, videos (power point with voice, animations, tutorials, and videos embedded from YouTube), article URLs, and various other supporting files. The course includes a variety of activities, including quizzes, discussion forums, chat, assignments, feedback, surveys, workshops, and the SCORM package. Additionally, this LMS includes video conferencing capabilities via the Big Blue Button. The material expert test results indicate that $90 \%$ of the samples are "very good." Expert testing on learning design equals $90 \%$ "very good," media expert testing equals $90 \%$ "very good," and student testing equals $95 \%$ "very good". It can be said that the developed online learning is feasible to use. The implementation stage is a critical step in putting the developed learning products into action. In online learning for media courses, digital-based media is used in the form of a DLSR camera simulator that is specially designed to be simulated by students as a camera that includes all of the camera's primary tool settings.

The final stage is to conduct an evaluation, the results of which will indicate whether the media is valid or invalid. This stage occurs following the distribution of online learning to students. The lecturer administers pretest and posttest questions to students to ascertain their ability levels. The data analysis stages are used to 
determine the effectiveness of online learning through the use of a t-test and the IBM SPSS Statistics application. To begin, the researchers evaluated the learning design through field trials. Both evaluations assessed student learning outcomes following the implementation of online learning activities Based on the analysis of the data obtained, it was determined that there was a significant increase in student learning outcomes in the experimental class; additionally, it was established that there was a difference between the tcount value of the control class and the experimental class $(3,558<5,610)$; thus, it can be concluded that there was an increase in learning outcomes associated with the use of online learning for media courses.

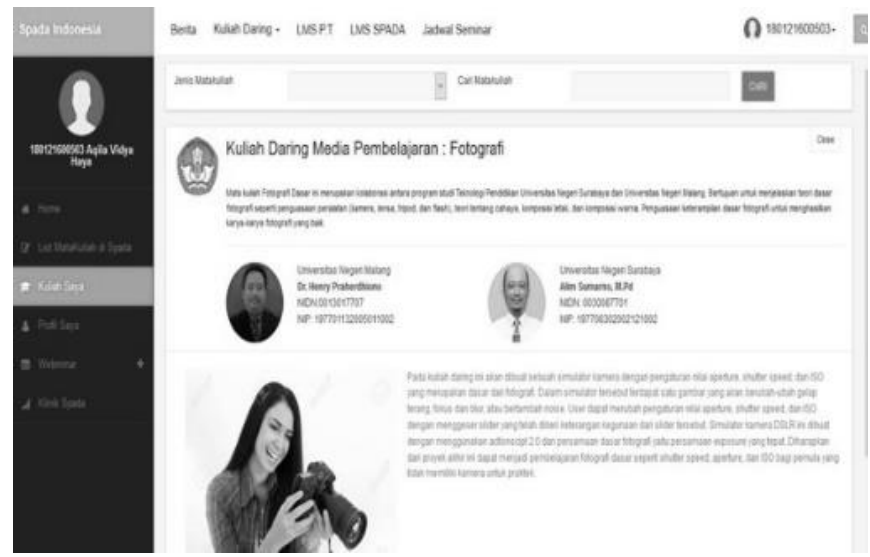

Picture 2. Development of Spada Learning Media

\section{Discussion}

Online learning in the Spada program of the State University of Surabaya's education technology study program is an online course for learning media courses. The online courses will be offered in the odd semester of the 2020/2021 school year via http://spada.tp.ac.id. This online mode of instruction incorporates innovative features such as online practice tests using camera simulators equipped with audio that can be used to evaluate practical courses. Additionally, students can access a variety of learning resources online (Fuad et al., 2020; Lapitan et al., 2021; Van Alten et al., 2020). Appropriate learning media must be aligned with the content and learning objectives to be accomplished, as stated in the statement (Choi et al., 2021; Selvaraj et al., 2021). The use of learning media, such as learning resources and tools, is tailored to the content of the learning materials and the desired outcomes (Klimova, 2021; Syauqi et al., 2020). Students can practice on the camera simulator or directly on the camera. Additionally, the media contains practical tests and assessments. This media is expected to be innovative in the sense that practical courses can be delivered online via appropriate media and can address learning objectives (Abramovitz et al., 2012; Gillett-Swan, 2017). Additionally, this media is extremely user friendly, which means that students can easily incorporate it into their online learning (Gerhardt-Szép et al., 2017; Solehana et al., 2019). At the moment, students in Indonesia, particularly the millennial generation, require online model learning through the use of internet technology (Arifuddin et al., 2020; Rusli \& Antonius, 2019). This is consistent with the SPADA Indonesia program's development of online courses. Students can easily find online courses through SPADA Indonesia. Students gain experience and knowledge from a variety of universities when they enroll in online courses. Naturally, this will enhance students' knowledge, skills, and attitudes (Amin et al., 2021; Khan et al., 2021). Interactions with the instructor take place in discussion forums that are open throughout the semester. Students can ask questions and also assist in answering questions from their peers. Students may also request additional time for discussion forums. There is one supporting lecturer who is in charge of this discussion forum and will respond to questions posed by students. Additionally, students can practice shooting online using a camera simulator.

At the conclusion of the learning process, the lecturer completes a student satisfaction questionnaire regarding the implementation of online learning and its support, which includes helpdesk services and learning support facilities. This data will be used by Unesa's e-learning managers to improve the system's performance and supporting facilities. Giving grades to partner students is accomplished by administering assessments manually and then submitting them to partner universities for entry into partner students' records, where they will later appear on the KHS of students who program this course. The findings of previous studies also stated that online learning could help students in self-study (Mahyoob, 2020; Owusu-Fordjour et al., 2020). Other research findings also state that effective online learning can help students learn anytime and anywhere (Bock et al., 2018; Lapitan et al., 2021; Maarop \& Embi, 2016). It can be concluded that online learning is effectively applied. The development of online learning can be helpful for students in carrying out learning caused by the 
limitations of distance and time. This bold course has innovative values, including independent online practice tests using camera simulators equipped with audio and video to make learning more interactive.

\section{CONCLUSION}

By conducting numerous trials, it is possible to conclude that the online learning that has been developed is viable for continuation and development in a much more positive direction. There was an increase in learning outcomes associated with the use of online learning for media courses. As a result, in the future, this online learning can be applied to classroom instruction.

\section{REFERENCES}

Abramovitz, B., Berezina, M., Berman, A., \& Shvartsman, L. (2012). A Blended Learning Approach in Mathematics. Teaching Mathematics Online: Emergent Technologies and Methodologies, 21. https://doi.org/10.4018/978-1-60960-875-0.ch002.

Alodwan, T., \& Almosa, M. (2018). The Effect of a Computer Program Based on Analysis, Design, Development, Implementation and Evaluation (ADDIE) in Improving Ninth Graders' Listening and Reading Comprehension Skills in English in Jordan. English Language Teaching, 11(4), 43. https://doi.org/10.5539/elt.v11n4p43.

Amin, I., Yousaf, A., Walia, S., \& Bashir, M. (2021). What Shapes E-Learning Effectiveness among Tourism Education Students? An Empirical Assessment during COVID19. Journal of Hospitality, Leisure, Sport and Tourism Education, $x x x(x x x x), 100337$. https://doi.org/10.1016/j.jhlste.2021.100337.

Amiti, F. (2020). Synchronous and asynchronous E-learning. European Journal of Open Education and ELearning Studies, 5(2), 60-70. https://doi.org/10.46827/ejoe.v5i2.3313.

Anggrellanggi, A., Supratiwi, M., Yusuf, M., Subagya, \& Martika, T. (2020). Penguatan Aksesibilitas Model Blended Learning pada Matakuliah Bahasa Indonesia bagi Mahasiswa Tunarungu dan Tunanetra. Special and Inclusive Education Journal (SPECIAL), 1(1), 25-30. https://doi.org/10.36456/SPECIAL.VOL1.NO1.A2085.

Anugrahana, A. (2020). Hambatan, Solusi dan Harapan : Pembelajaran Daring Selama Masa Pandemi Covid-19 Oleh Guru Sekolah Dasar. Scholaria: Jurnal Pendidikan Dan Kebudayaan, 10(3), 282-289. https://doi.org/10.24246/j.js.2020.v10.i3.p282-289.

Arifuddin, Suwatra, \& Mahadewi. (2020). Pengembangan Konten E-learning Berorientasi Pendidikan Karakter Pada Mata Pelajaran Seni Budaya. Jurnal Edutech Undiksha, 8(2). https://doi.org/10.23887/jeu.v8i2.28942.

Astuti, M., Arifin, Z., Mutohhari, F., \& Nurtanto, M. (2021). Competency of Digital Technology: The Maturity Levels of Teachers and Students in Vocational Education in Indonesia. Journal of Education Technology, 5(2), 254-262. https://doi.org/10.23887/jet.v5i3.35108.

Beaunoyer, E., Torres, L. H., Maessen, L., \& Guitton, M. J. (2020). Grieving in the digital era: Mapping online support for grief and bereavement. Patient Education and Counseling, 103(11). https://doi.org/10.1016/j.pec.2020.06.013.

Benavides-Varela, S., Callegher, C. Z., Fagiolini, B., Leo, I., Altoè, G., \& Lucangeli, D. (2020). Effectiveness of digital-based interventions for children with mathematical learning difficulties: A meta-analysis. Computers \& Education, 157. https://doi.org/10.1016/j.compedu.2020.103953.

Bervell, B., \& Arkorful, V. (2020). LMS-Enabled Blended Learning Utilization in Distance Tertiary Education: Establishing the Relationships Among Facilitating Conditions, Voluntariness of Use and Use Behaviour. International Journal of Educational Technology in Higher Education, 17(1), 6. https://doi.org/10.1186/s41239-020-0183-9.

Bock, A., Modabber, A., Kniha, K., Lemos, M., Rafai, N., \& Hölzle, F. (2018). Blended learning modules for lectures on oral and maxillofacial surgery. British Journal of Oral and Maxillofacial Surgery, 56(10), 956-961. https://doi.org/10.1016/j.bjoms.2018.10.281

Bosshardt, W., \& Chiang. (2018). Evaluating the effect of online principles courses on long-term outcomes. International Review of Economics Education. https://doi.org/10.1016/j.iree.2018.03.001.

Cahyadi, R. A. H. (2019). Pengembangan Bahan Ajar Berbasis Addie Model. Halaqa: Islamic Education Journal, 3(1), 35. https://doi.org/10.21070/halaqa.v3i1.2124.

Cavanagh, T., Chen, B., Lahcen, R. A. M., \& Paradiso, J. (2020). Constructing a Design Framework and Pedagogical Approach for Adaptive Learning in Higher Education: A Practitioner's Perspective. The International Review of Research in Open and Distributed Learning, 21(1), 172-196. https://doi.org/10.19173/IRRODL.V21I1.4557.

Chang, H.-Y., Wu, H.-F., Chang, Y.-C., Tseng, Y.-S., \& Wang, Y.-C. (2021). The effects of a virtual simulationbased, mobile technology application on nursing students' learning achievement and cognitive load: 
Randomized controlled trial. International Journal of Nursing Studies, 120. https://doi.org/10.1016/j.ijnurstu.2021.103948.

Chao, J. Y., Tzeng, P. W., \& Po, H. Y. (2017). The study of problem solving process of e-book PBL course of atayal senior high school students in Taiwan. Eurasia Journal of Mathematics, Science and Technology Education, 13(3), 1001-1012. https://doi.org/10.12973/eurasia.2017.00654a.

Chin, K.-Y., \& Wang, C.-S. (2021). Effects of augmented reality technology in a mobile touring system on university students' learning performance and interest. Australasian Journal of Educational Technology, 37(1). https://doi.org/10.14742/ajet.5841.

Choi, J. J., Robb, C. A., Mifli, M., \& Zainuddin, Z. (2021). University students' perception to online class delivery methods during the COVID-19 pandemic: A focus on hospitality education in Korea and Malaysia. Journal of Hospitality, Leisure, Sport and Tourism Education, 29(August), 100336. https://doi.org/10.1016/j.jhlste.2021.100336.

Desyandri, D., Muhammadi, M., Mansurdin, M., \& Fahmi, R. (2019). Development of integrated thematic teaching material used discovery learning model in grade V elementary school. Jurnal Konseling Dan Pendidikan, 7(1), 16. https://doi.org/10.29210/129400

Dhawan, S. (2020). Online Learning: A Panacea in the Time of COVID-19 Crisis. Journal of Educational Technology Systems, 49(1), 5-22. https://doi.org/10.1177/0047239520934018.

Duncan, M. J., Smith, M., \& Cook, K. (2013). Implementing online problem based learning (PBL) in postgraduates new to both online learning and PBL: An example from strength and conditioning. Journal of Hospitality, Leisure, Sport and Tourism Education, 12(1), 79-84. https://doi.org/10.1016/j.jhlste.2012.11.004.

Fitriyani, Y., Fauzi, I., \& Sari, M. Z. (2020). Motivasi Belajar Mahasiswa Pada Pembelajaran Daring Selama Pandemik Covid-19. Profesi Pendidikan Dasar, 7(1), 121-132. https://doi.org/10.23917/ppd.v7i1.10973.

Fuad, M., Ariyani, F., Suyanto, E., \& Shidiq, A. S. (2020). Exploring teachers' tpck: Are indonesian language teachers ready for online learning during the covid-19 outbreak? Universal Journal of Educational Research, 8(11B), 6091-6102. https://doi.org/10.13189/ujer.2020.082245.

Gerhardt-Szép, S., Dreher, S., Rüttermann, S., \& Weberschock, T. (2017). Konzeption und Implementierung eines neuartigen E-Learning-Moduls mit EbM-Lerninhalten im Fach Zahnerhaltungskunde. Zeitschrift Für Evidenz, Fortbildung Und Qualität Im Gesundheitswesen, 127-128, 72-78. https://doi.org/10.1016/j.zefq.2017.09.001.

Gillett-Swan, J. (2017). The Challenges of Online Learning: Supporting and Engaging the Isolated Learner. Journal of Learning Design, 10(1). https://doi.org/10.5204/jld.v9i3.293.

Hashim, H. (2018). Application of Technology in the Digital Era Education. International Journal of Research in Counseling and Education, 1(2), 1. https://doi.org/10.24036/002za0002.

Helsa, Y, Ariani, Y., \& Kenedi, A. (2021). Digital Class Model in Mathematics Learning in Elementary School Using Social Learning Network Schoology. 382(Icet 2019), 2016-2019. https://doi.org/10.4108/eai.411-2020.2304599.

Helsa, Yullys, \& Kenedi, A. K. (2019). Edmodo-Based Blended Learning Media in Learning Mathematics. Journal of Teaching and Learning in Elementary Education (Jtlee), 2(2), 107-117. https://doi.org/10.33578/jtlee.v2i2.7416.

Hwang, G.-J., Wang, S.-Y., \& Lai, C.-L. (2021). Effects of a social regulation-based online learning framework on students' learning achievements and behaviors in mathematics. Computers \& Education, 160. https://doi.org/10.1016/j.compedu.2020.104031.

Idris, S., Malim, T., Ab, W., Wan, A., Development, G., \& Jeli, K. (2018). Adaptation of ADDIE instructional model in developing educational website for language learning. Global Journal Al-Thaqafah, 8(2), 7 16.

Islam Sarker, M. N., Wu, M., Cao, Q., Alam, G. M. M., \& Li, D. (2019). Leveraging Digital Technology for Better Learning and Education: A Systematic Literature Review. International Journal of Information and Education Technology, 9(7), 453-461. https://doi.org/10.18178/ijiet.2019.9.7.1246.

Joshi, O., Chapagain, B., Kharel, G., Poudyal, N. C., Murray, B. D., \& Mehmood, S. R. (2020). Benefits and Challenges of Online Instruction in Agriculture and Natural Resource Education. Interactive Learning Environments, 1-12. https://doi.org/10.1080/10494820.2020.1725896.

Kalyuga, S. (2012). Interactive distance education: A cognitive load perspective. Journal of Computing in Higher Education. https://doi.org/10.1007/s12528-012-9060-4.

Kebritchi, M., Lipschuetz, A., \& Santiague, L. (2017). Issues and Challenges for Teaching Successful Online Courses in Higher Education. Journal of Educational Technology Systems, 46(1). https://doi.org/10.1177/0047239516661713.

Khairudin, M., Triatmaja, A. K., Istanto, W. J., \& Azman, M. N. A. (2019). Mobile virtual reality to develop a 
virtual laboratorium for the subject of digital engineering. International Journal of Interactive Mobile Technologies, 13(4), 79-95. https://doi.org/10.3991/ijim.v13i04.10522.

Khan, M. A., Vivek, Nabi, M. K., Khojah, M., \& Tahir, M. (2021). Students' Perception towards E-Learning During Covid-19 Pandemic In India: An Empirical Study. Sustainability, 13(1). https://doi.org/10.3390/su13010057.

Klimova, B. (2021). ScienceDirect An Insight into Online Foreign Language Learning and Teaching in the Era of COVID-19 Pandemic. Procedia Computer Science, 192, 1787-1794. https://doi.org/10.1016/j.procs.2021.08.183.

Koh, J. H. L., Herring, S. C., \& Hew, K. F. (2010). Project-based learning and student knowledge construction during asynchronous online discussion. Internet and Higher Education, 13(4), 284-291. https://doi.org/10.1016/j.iheduc.2010.09.003.

Kristanto, A. (2021). Integration of a Constructivism Approach in E-learning Photography Subjects: Feasibility and Effectiveness in Learning. Journal of Education Technology, 5(2), 167-174.

Kristanto, A., Sulistiowati, ., \& Pradana, H. D. (2021). Brain-Based Online Learning Design in The Disruptive Era for Students in University. Journal of Educational and Social Research, 11(6), 277. https://doi.org/10.36941/jesr-2021-0147.

Lapada, A. A., Miguel, F. F., Robledo, D. A. R., \& Alam, Z. F. (2020). Teachers' Covid-19 Awareness, Distance Learning Education Experiences and Perceptions towards Institutional Readiness and Challenges. International Journal of Learning, Teaching and Educational Research, 19(6), 127-144. https://doi.org/10.26803/ijlter.19.6.8.

Lapitan, L. D., Tiangco, C. E., Sumalinog, D. A. G., Sabarillo, N. S., \& Diaz, J. M. (2021). An effective blended online teaching and learning strategy during the COVID-19 pandemic. Education for Chemical Engineers, 35(May 2020), 116-131. https://doi.org/10.1016/j.ece.2021.01.012.

Maarop, A. H., \& Embi, M. A. (2016). Implementation of Blended Learning in Higher Learning Institutions: A Review of Literature. ResearchGate, 9(3), 41. https://doi.org/10.5539/ies.v9n3p4.

Mahasneh, D., Shoqirat, N., Singh, C., \& Hawks, M. (2021). "From the classroom to Dr. YouTube": nursing students' experiences of learning and teaching styles in Jordan. Teaching and Learning in Nursing, 16(1). https://doi.org/10.1016/j.teln.2020.09.008.

Mahyoob, M. (2020). Challenges of e-Learning during the COVID-19 Pandemic Experienced by EFL Learners. Arab World English Journal (AWEJ), 11(4).

Molina, A. I., Navarro, Ó., Ortega, M., \& Lacruz, M. (2018). Evaluating multimedia learning materials in primary education using eye tracking. Computer Standards \& Interfaces, 59, 45-60. https://doi.org/https://doi.org/10.1016/j.csi.2018.02.004

Morze, N., Varchenko-Trotsenko, L., Terletska, T., \& Smyrnova-Trybulska, E. (2021). Implementation of adaptive learning at higher education institutions by means of Moodle LMS. Journal of Physics: Conference Series, 1840(1). https://doi.org/10.1088/1742-6596/1840/1/012062.

Nuryadi, N., Kurniawan, L., \& Kholifa, I. (2020). Developing mobile learning based on ethnomathematics viewed from adaptive e-learning: Study of two dimensions geometry on Yogyakarta palace's chariot. International Journal of Education and Learning, 2(1), 32-41. https://doi.org/10.31763/ijele.v2i1.85.

Ogbonna, C. G., Ibezim, N. E., \& Obi, C. A. (2019). Synchronous versus asynchronous e-learning in teaching word processing: An experimental approach. South African Journal of Education, 39(2), 1-15. https://doi.org/10.15700/saje.v39n2a1383.

Owusu-Fordjour, C., Koomson, C. K., \& Hanson, D. (2020). The Impact of Covid-19 on Learning-The Perspective of the Ghanaian Student. European Journal of Education Studies, 7(3), 88-101. https://doi.org/10.5281/zenodo.3753586.

Purwitaningrum, R., \& Prahmana, R. C. I. (2021). Developing instructional materials on mathematics logical thinking through the Indonesian realistic mathematics education approach. International Journal of Education and Learning, 3(1), 13-19. https://doi.org/10.31763/ijele.v3i1.178.

Putri, V. D. (2020). Layanan Bimbingan dan Konseling Daring Selama Masa Pandemi COVID-19. Jurnal Bimbingan Konseling Pendidikan Islam, 1(2), 7-16. https://doi.org/10.47453/coution.v1i2.95.

Qazi, A., Naseer, K., Qazi, J., Alsalman, H., Naseem, U., Yang, S., Hardaker, G., \& Gumaei, A. (2020). Children and Youth Services Review Conventional to online education during COVID-19 pandemic : Do develop and underdeveloped nations cope alike. Children and Youth Services Review, 119(October), 105582. https://doi.org/10.1016/j.childyouth.2020.105582.

Richardson, J. C., Besser, E., Koehler, A., Lim, J. E., \& Strait, M. (2016). Instructors' perceptions of instructor presence in online learning environments. International Review of Research in Open and Distance Learning, 17(4). https://doi.org/10.19173/irrodl.v17i4.2330.

Rusli, M., \& Antonius, L. (2019). Meningkatkan Kognitif Siswa SMAN I Jambi Melalui Modul Berbasis EBook Kvisoft Flipbook Maker. Jurnal Sistem Komputer Dan Informatika (JSON), 1(1), 59. 
https://doi.org/10.30865/json.v1i1.1397.

Sadegi, M. (2019). A Shift Ftom Classroom to Distance Learning: Advantages and Limitation. International Journal of Research in English Education (IJREE), 4(1). https://doi.org/10.29252/ijree.4.1.80.

Sadikin, A., \& Hamidah, A. (2020). Pembelajaran Daring di Tengah Wabah Covid-19. BIODIK: Jurnal Ilmiah Pendidikan Biologi, 6(2). https://doi.org/https://doi.org/10.22437/bio.v6i2.9759.

Sadikin, Ali, \& Hamidah, A. (2020). Pembelajaran Daring di Tengah Wabah Covid-19. Biodik, 6(2), $109-119$. https://doi.org/10.22437/bio.v6i2.9759.

Satyawan, I. M., Wahjoedi, \& Swadesi, I. K. I. (2020). The Effectiveness of Online Learning Through UNDIKSHA E-Learning During the COVID-19 Pandemic in the Physical Education Study Program. Journal of Education Technology, 5(2), 191-199. https://doi.org/10.23887/jet.v5i2.32364.

Selvaraj, A., Radhin, V., KA, N., Benson, N., \& Mathew, A. J. (2021). Effect of pandemic based online education on teaching and learning system. International Journal of Educational Development, 85(May), 102444. https://doi.org/10.1016/j.ijedudev.2021.102444.

Sidhu, R., \& Gage, W. H. (2021). Enhancing the odds of adopting e-learning or community-focused experiential learning as a teaching practice amongst university faculty. Heliyon, 7(4). https://doi.org/10.1016/j.heliyon.2021.e06704.

Sintema, E. J. (2020). Effect of COVID-19 on the performance of grade 12 students: Implications for STEM education. Eurasia Journal of Mathematics, Science and Technology Education, 16(7), 1-6. https://doi.org/10.29333/EJMSTE/7893.

Solehana, L., Asrori, A., \& Usman, A. (2019). The Development of E-Learning Teaching Material Based on Edmodo on Basic Competencies of National Integration at Class X of Senior High School. Journal Of Education, Teaching And Learning, 4(2). https://doi.org/10.26737/jetl.v4i2.1914.

Sugiyono. (2016). Metode Penelitian Kuantitatif, Kualitatif dan $R \& D$. IKAPI.

Summak, M. S., Bağlibel, M., \& Samancioğlu, M. (2010). Technology readiness of primary school teachers: A case study in Turkey. Procedia - Social and Behavioral Sciences, 2(2), 2671-2675. https://doi.org/10.1016/J.SBSPRO.2010.03.393.

Sutarto, S., Sari, D. P., \& Fathurrochman, I. (2020). Teacher Strategies in Online Learning to Increase Students ' Interest in Learning During COVID-19 Pandemic. Jurnal Konseling Dan Pendidikan, 8(3Sutarto, S., Sari, D. P., Fathurrochman, I. (2020). Teacher Strategies in Online Learning to Increase Students , Interest in Learning During COVID-19 Pandemic. Jurnal Konseling Dan Pendidikan, 8(3), 129-137. https://doi.org/10.29210/147800), 129-137. https://doi.org/10.29210/147800.

Syauqi, K., Munadi, S., \& Triyono, M. B. (2020). Students' perceptions toward vocational education on online learning during the COVID-19 pandemic. Internasional Journal of Evaluation and Reseacrh In Education (IJEE), 9(4). https://doi.org/10.11591/ijere.v9i4.20766.

Tajvidi, M., Ghiyasvandian, S., \& Salsali, M. (2014). Probing concept of critical thinking in nursing education in Iran: A concept analysis. Asian Nursing Research, 8(2), 158-164. https://doi.org/10.1016/j.anr.2014.02.005.

Tang, Y. M., Chen, P. C., Law, K. M. Y., Wu, C. H., Lau, Y., Guan, J., He, D., \& Ho, G. T. S. (2021). Comparative analysis of Student's live online learning readiness during the coronavirus (COVID-19) pandemic in the higher education sector. Computers \& Education, 168, 104211. https://doi.org/10.1016/j.compedu.2021.104211.

Udayani, N. K. R. T. K., Wibawa, I. M. C., \& Rati, N. W. (2021). Development Of E-Comic Learning Media On The Topic Of The Human Digestive System. Journal of Education Technology, 5(3), 472-481. https://doi.org/10.23887/jet.v5i3.34732.

Van Alten, D. C. D., Phielix, C., Janssen, J., \& Kester, L. (2020). Self-regulated learning support in flipped learning videos enhances learning outcomes. Computers and Education, 158(August), 104000. https://doi.org/10.1016/j.compedu.2020.104000.

Waqar, S., Shafiq, S., \& Hasan, S. (2016). Impact of Procrastination and Academic Motivation on Academic Self-efficacy among University Students. IOSR Journal Of Humanities And Social Science (IOSRJHSS, 21(6), 7-13. https://doi.org/10.9790/0837-2106040713.

Wijaya, H., Tari, E., Sumule, L., Weismann, I. T. J., \& Supartini, T. (2021). Online Learning Evaluation in Higher Education: Study Survey Method. Journal of Education Technology, 5(3), 401-408. https://doi.org/10.23887/jet.v5i3.35466.

Wulandari, I. G. A. A. M., Sudatha, I. G. W., \& Simamora, A. H. (2020). Pengembangan Pembelajaran Blended Pada Mata Kuliah Ahara Yoga Semester II di IHDN Denpasar. Jurnal Edutech Undiksha, 8(1), 1. https://doi.org/10.23887/jeu.v8i1.26459.

Yustika, G. P., Subagyo, A., \& Iswati, S. (2019). Masalah Yang Dihadapi Dunia Pendidikan Dengan Tutorial Online: Sebuah Short Review. Tadbir: Jurnal Studi Manajemen Pendidikan, 3(2), 195. https://doi.org/10.29240/jsmp.v3i2.1178. 